\title{
PERBANDINGAN KUALITAS SUPLEMEN MINYAK IKAN LAYANG (Decapterus ruselli) MENGGUNAKAN BENTONIT DENGAN BERBAGAI KONSENTRASI PADA TAHAP BLEACHING
}

\section{THE COMPARISON OF QUALITY OF LAYANG FISH (Decapterus ruselli) OIL SUPPLEMENT BLEACHED WITH VARIOUS CONCENTRATIONS OF BENTONITE}

\author{
Yanu Andhiarto, Santi Wijaya \\ Program Studi S1 Farmasi, Fakultas Kedokteran, Universitas Hang Tuah Surabaya \\ Jl. Arief rachman Hakim No. 150, Sukolilo, Surabaya, Indonesia \\ Email: yanu.andhiarto@hangtuah.ac.id (Yanu Andhiarto)
}

\begin{abstract}
ABSTRAK
Suplemen minyak ikan termasuk dalam salah satu produk pengembangan hasil perikanan laut yang cukup potensial untuk dikembangkan terutama dalam bidang kefarmasian karena mengandung asam lemak tidak jenuh yang merupakan komponen esensial bagi tubuh manusia, terutama asam lemak rantai panjang asam eikosapentaenoat (EPA) dan asam dokosaheksaenoat (DHA). Minyak ikan hasil ekstraksi mengandung pengotor sehingga perlu dilakukan pemurnian untuk mendapatkan minyak ikan dengan mutu baik. Bentonit merupakan adsorben yang dapat meningkatkan mutu dan memperbaiki warna minyak ikan. Penelitian ini bertujuan untuk menentukan karakteristik mutu dan perbandingan karakteristik mutu hasil pemurnian minyak ikan layang (Decapterus russelli) menggunakan bentonit konsentrasi 1, 3, dan 5\% pada tahap bleaching. Penelitian ini dilakukan 3 tahapan yaitu degumming, refining, dan bleaching, kemudian dilakukan uji karakteristik mutu minyak ikan. Dari hasil penelitian, pemurnian minyak ikan layang terbaik pada konsentrasi bentonit 3\% menghasilkan minyak ikan yang memenuhi persyaratan International Fish Oil Standard (IFOS) dengan nilai kadar asam lemak bebas sebesar $0,4406 \pm 0,0265 \%$ (b/b); bilangan peroksida sebesar $3,9953 \pm 0,0742 \mathrm{mEq} / \mathrm{kg}$; bilangan $\mathrm{p}$-anisidin sebesar $13,6624 \pm 1,9574 \mathrm{mEq} / \mathrm{kg}$; bilangan total oksidasi sebesar $21,6531 \pm 1,8150 \mathrm{mEq} / \mathrm{kg}$; dan kejernihan berturut-turut 74,6996 $\pm 1,9363 ; \quad 94,4950 \pm 1,5724 ; \quad 95,1060 \pm 1,667 ; \quad 95,6906 \pm 1,4371 ; \quad$ dan $95,9356 \pm 1,3427 \% \mathrm{~T}$ berturut-turut pada panjang gelombang $(\lambda) 450,550,620,665$, dan $700 \mathrm{~nm}$. Hasil penelitian menunjukkan bahwa pemberian bentonit berpotensi sebagai adsorben dalam proses pemurnian minyak ikan kasar ditandai dengan karakteristik mutu menjadi lebih baik. Hasil uji one-way ANOVA dan Kruskal-Wallis perbedaan konsentrasi bentonit menunjukkan perbedaan nyata terhadap nilai analisis bilangan asam lemak bebas dan kejernihan. Namun tidak berbeda nyata terhadap nilai analisis bilangan peroksida, $\mathrm{p}$-anisidin, dan bilangan total oksidasi.
\end{abstract}

Kata kunci: bentonit, bilangan asam lemak bebas, bilangan peroksida, kejernihan, minyak ikan layang. 


\begin{abstract}
Fish oil supplements contain unsaturated fatty acids, including eicosapentanoic acid (EPA) and docosahexanoic acid (DHA), that are essential for human body. The extraction process of fish oil contains impurities so purification process is needed to obtain good quality of fish oil. Bentonite is an adsorbent that can improve the quality and the color of fish oil. The aims of this study are to determine the quality characteristics and comparing the quality characteristics of layang fish (Decapterus ruselli) oil obtained from bleaching process with bentonite at concentrations of 1,3 , and $5 \%$. This research was conducted 3 stages they were degumming, refining, and bleaching, as well as testing the quality characteristics of the obtained fish oils. The results demonstrated that the best Layang fish oil was obtained from refining and bleaching with 3\% bentonite, that produced the fish oil that meet the requirement of International Fish Oil Standart (IFOS) with a value of free fatty acid content of $0.4406 \pm 0.0265 \%(b / b)$; peroxide value of $3.9953 \pm 0.0742$ meq $/ \mathrm{kg}, \mathrm{p}$-anisidine value of $13.6624 \pm 1.9574 \mathrm{meq} / \mathrm{kg}$; value of oxidation total of $21.6531 \pm 1.8150 \mathrm{meq} / \mathrm{kg}$ and clarity of $74.6996 \pm 1.9363 ; 94.4950 \pm 1.5724$; $95.1060 \pm 1.667 ; 95.6906 \pm 1.4371$; and $95.9356 \pm 1.3427$ at wavelenght $(\lambda)$ of 450,550 , 620,665 , and $700 \mathrm{~nm}$, respectively. The result showed that bentonite was a good adsorbent in the process of purification of fish oil that was capable of increasing the quality characteristics of the oils. The one-way ANOVA and Kruskal-Wallis tests indicated that bentonite concentration significantly influenced the value of free fatty acid and clarity, but did not significantly affected the value of peroxide, p-anisidin, and total oxidation of the oils.
\end{abstract}

Key words: bentonite, clarity, free fatty acid, layang fish oil, peroxide. 


\section{Pendahuluan}

Suplemen minyak ikan merupakan asupan minyak esensial yang mengandung banyak nutrisi penting yang dibutuhkan oleh tubuh manusia karena mengandung sekitar 25\% asam lemak jenuh dan 75\% asam lemak tak jenuh (Hidayaturrahmah et al., 2016). Asam lemak yang dominan dalam minyak ikan yaitu asam lemak tak jenuh majemuk atau asam poliena (polyunsaturated fatty acids/PUFA), salah satunya adalah omega-3 terutama asam eikosapentaenoat (EPA) dan asam dokosaheksaenoat (DHA). Asam lemak omega-3 penting bagi kesehatan yaitu dapat mencegah penyakit jantung, menghambat perkembangan kanker, menurunkan pembentukan LDL, VLDL kolesterol yang beresiko terhadap penyakit jantung, dan penting bagi perkembangan otak dan retina (Estiasih, 2009).

Ikan layang (Decapterus russelli) yang tergolong dalam ikan pelagis kecil merupakan ikan hasil tangkapan utama kapal purse seine di Laut Jawa dengan produksi $60 \%$ dari hasil tangkapan total ikan pelagis kecil lainnya. Ikan layang mengandung lemak tinggi yaitu sebanyak 5,74\% (Sutarjo, 2017). Minarny et al. (2014) mengungkapkan bahwa ikan layang mengandung omega-3 sebanyak $11,76 \%$. Dengan harga yang cukup terjangkau, stok ikan yang melimpah, dan kandungan minyak yang tinggi menyebabkan ikan layang berpeluang besar untuk dikembangkan sebagai suplemen minyak ikan.

Untuk memperoleh grade suplemen minyak ikan yang siap dikonsumsi, minyak ikan yang diperoleh dari ekstraksi perlu dimurnikan. Dengan demikian minyak ikan dapat dimanfaatkan secara optimal. Tahaptahap pemurnian minyak terdiri dari degumming, refining, bleaching (pemucatan), deodorisasi, dan winterisasi (Estiasih, 2009). Minyak kasar hasil sampling industri maupun hasil ekstraksi tentunya masih mengandung beberapa pengotor, baik yang terlarut maupun yang tidak terlarut dalam minyak, dimana pengotor-pengotor tersebut dapat menyebabkan menurunnya kualitas dan warna gelap yang tidak diinginkan pada minyak. Tahapan bleaching penting dilakukan karena pada umumnya konsumen menghendaki minyak yang bening dan jernih. Selain itu tahap bleaching juga berperan untuk mengurangi komponen minor seperti aroma, senyawa bersulfur, dan logam-logam berat. Pada dasarnya 
tahapan bleaching ini merupakan proses adsorpsi dengan menggunakan adsorben. Adsorben yang digunakan dalam penelitian ini yaitu bentonit yang merupakan suatu bleaching earth (Estiasih, 2009).

Karakteristik minyak ikan dapat ditentukan dengan menghitung nilai parameter oksidasi baik primer maupun sekunder, karena parameter tersebut menentukan kualitas minyak ikan yang dihasilkan (Suseno et al., 2016). Parameter karakteristik mutu yang dilakukan dalam penelitian ini adalah dengan menganalisis bilangan peroksida, bilangan asam lemak bebas, bilangan $p$ anisidin, dan total oksidasi. Selain itu peneliti melakukan uji kejernihan. Kejernihan memiliki peranan sebagai daya tarik bagi konsumen dalam memilih minyak ikan. Kejernihan yang tinggi pada minyak menunjukan bahwa pengotorpengotor yang terdapat pada minyak tersebut semakin sedikit. Berdasarkan latar belakang tersebut, penelitian ini bertujuan untuk menentukan karakteristik mutu dan perbandingan karakteristik mutu hasil pemurnian minyak ikan layang menggunakan bentonit konsentrasi 1, 3, dan 5\% pada tahap bleaching. Hasil penelitian ini diharapkan dapat menghasilkan minyak ikan yang berkualitas sehingga menjadi titik awal pengembangan potensi minyak ikan Indonesia untuk dapat bersaing di pasar internasional dan menjadikan Indonesia suatu saat nanti sebagai produsen minyak ikan dunia.

\section{Metode Penelitian}

Penelitian dilaksanakan di Laboratorium Fitokimia, Program Studi Farmasi, Fakultas Kedokteran, Universitas Hang Tuah Surabaya dari Februari 2018 sampai bulan Juni 2018. Jenis metode penelitian ini adalah eksperimental dengan metode Completely Randomized Design (CRD), dimana pada penelitian tidak terdapat perlakuan kelompok kontrol. Penelitian dilakukan pada kondisi lingkungan, alat, bahan atau media yang dipakai seragam atau homogen. Populasi dalam penelitian ini adalah ikan pelagis kecil. Sedangkan sampel dalam penelitian ini adalah minyak ikan layang kasar yang diperoleh dari hasil ekstraksi minyak ikan menggunakan metode ekstraksi Hara dan Radin (Hara dan Radin, 1978).

Teknik pengambilan sampel menggunakan probability yaitu simple random sampling, dimana ikan layang diberi nomor kemudian dilakukan pengocokan. Nomor yang keluar dari 
hasil pengocokan tersebut merupakan nomor dari ikan layang yang digunakan. Variabel bebas pada penelitian ini adalah perbedaan penambahan bentonit pada proses bleaching dengan berbagai konsentrasi (1, 3, dan 5\%). Variabel tergantungnya adalah parameter karakteristik mutu yang dilakukan pada hasil pemurnian minyak ikan layang yaitu bilangan asam lemak bebas, bilangan peroksida, bilangan anisidin, nilai total oksidasi, dan kejernihan. Sedangkan Variabel terikat berupa spesies, umur, dan bagian dari ikan layang.

\section{Alat dan Bahan}

Alat yang digunakan dalam penelitian ini antara lain spektrofotometer UV-VIS, oven, waterbath, magnetic stirrer, timbangan digital, sentrifus, ball filler, perangkat lunak SPSS Statistics 22. Sedangkan bahan yang digunakan dalam penelitian ini antara lain minyak ikan layang hasil ekstraksi metode Hara dan Radin, bentonit, $\mathrm{H}_{2} \mathrm{SO}_{4} 1 \mathrm{~N}$, akuades, $\mathrm{NaCl} 5 \%$ (b/v), $\mathrm{NaOH} 9,5 \%(b / v)$, indikator pati $1 \%$ $(b / v)$, indikator fenolftalein (indikator $\mathrm{PP}), \mathrm{KOH} 0,1 \mathrm{~N}$, asam asetat glasial, kloroform, larutan $\mathrm{KI}$ jenuh, natrium tiosulfat $\left(\mathrm{Na}_{2} \mathrm{~S}_{2} \mathrm{O}_{3}\right) 0,1 \mathrm{~N}$, etanol $95 \%$, isooktana, p-anisidin, minyak ikan komersial, dan pelarut $\mathrm{n}$-heksana.
Jalannya Penelitian

Penelitian ini dilakukan dengan beberapa tahapan yaitu aktivasi bentonit, pemurnian minyak ikan dengan berbagai macam konsentrasi bentonit, dan uji karakteristik mutu minyak ikan. Aktivasi bentonit dilakukan secara kimia yaitu bentonit dicampur dengan $\mathrm{H}_{2} \mathrm{SO}_{4} 1 \mathrm{~N}$ (1 gram bentonit : 10 $\mathrm{mL}$ asam) ke dalam gelas beaker. Aktivasi ini dilakukan di waterbath selama dua jam pada suhu $70{ }^{\circ} \mathrm{C}$. Bentonit yang telah diaktivasi kemudian disaring dan dicuci dengan air suhu $75^{\circ} \mathrm{C}$ sampai $\mathrm{pH}$ air pencuci netral. Bentonit kemudian dikeringkan dalam oven pada suhu $105{ }^{\circ} \mathrm{C}$ sampai berat bentonit konstan (Handayani dan Yusnimar, 2013).

Pemurnian minyak ikan dilakukan dengan menimbang minyak ikan layang hasil dari ekstraksi metode Hara dan Radin terlebih dahulu. Kemudian pemurnian minyak ikan kasar (crude fish oil) dilakukan dengan tahapan degumming, refining, dan bleaching. Penelitian ini didasarkan pada penelitian sebelumnya dengan perbedaan pada tahap degumming dengan penambahan $\mathrm{NaCl} 5 \%(\mathrm{~b} / \mathrm{v})$, pada tahap refining penambahan $\mathrm{NaOH}$ sesuai perhitungan treat, dan pada tahap bleaching 
digunakan konsentrasi bentonit 1,3 , dan

5\%. Selanjutnya dilakukan uji karakteristik mutu minyak ikan dan uji kejernihan. Minyak ikan berkualitas baik harus mempunyai kadar asam lemak bebas, kotoran dan air, tingkat oksidasi, warna, dan kadar logam yang tidak melebihi batas maksimum yang ditetapkan berdasarkan standar minyak ikan (Estiasih, 2009). Standar minyak ikan murni menurut International Fish Oil Standard (IFOS, 2014), yaitu bilangan peroksida $\leq 5,0 \mathrm{mEq} / \mathrm{kg}$, bilangan asam lemak bebas $\leq 1,50 \mathrm{mEq} / \mathrm{kg}$, bilangan $p$ anisidin $\leq 20,0 \mathrm{mEq} / \mathrm{kg}$, dan bilangan total oksidasi $\leq 19,5 \mathrm{mEq} / \mathrm{kg}$.

Data yang diperoleh dalam penelitian ini dengan penambahan bentonit berbagai konsentrasi $(1,3$, dan
5\%) berupa hasil analisis karakteriktik mutu minyak ikan meliputi bilangan asam lemak bebas, bilangan peroksida, bilangan anisidin, bilangan total oksidasi, dan kejernihan. Kemudian data yang diperoleh dianalisis menggunakan program komputer IBM SPSS Statistics 22.

\section{Hasil dan Pembahasan}

Minyak ikan layang setelah pemurnian memiliki warna kuning jernih dan bau amis berkurang dibandingkan dengan minyak ikan sebelum dilakukan pemurnian. Perbedaan penampakan fisik minyak ikan layang setelah pemurnian menggunakan bentonit pada tahap bleaching pada konsentrasi 1 , 3, dan $5 \%$ dapat dilihat pada Gambar 1.

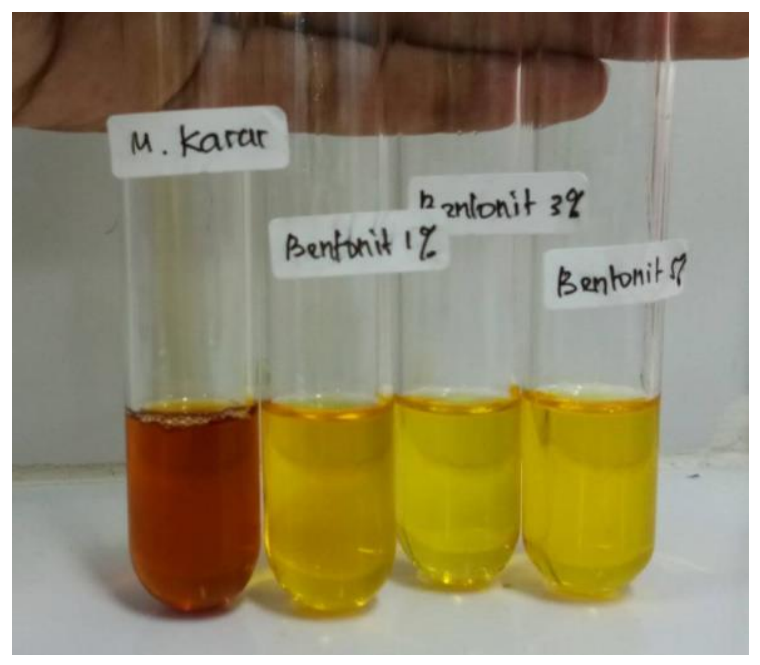

Gambar 1. Penampakan fisik minyak ikan layang (Decapterus russelli) setelah pemurnian. 
Vol.15 No. 02 Desember 2018

Tabel 1. Karakteristik minyak ikan layang (Decapterus russelli) setelah pemurnian

\begin{tabular}{lcccc}
\hline Karakteristik & $\mathbf{P}_{\mathbf{1}}$ & $\mathbf{P}_{\mathbf{3}}$ & $\mathbf{P}_{\mathbf{5}}$ & IFOS \\
\hline $\begin{array}{l}\text { Kadar asam lemak } \\
\text { bebas }(\% \mathrm{~b} / \mathrm{b}) \pm \mathrm{SD}\end{array}$ & $0,2449 \pm 0,0296$ & $0,4406 \pm 0,0265$ & $0,6616 \pm 0,0307$ & $\leq 1,50 \% \mathrm{~b} / \mathrm{b}$ \\
$\begin{array}{l}\text { Bilangan peroksida } \\
\text { (mEq/kg) } \pm \text { SD }\end{array}$ & $7,2757 \pm 1,084145$ & $3,9953 \pm 0,0742$ & $7,9675 \pm 0,0638$ & $\leq 5,00 \mathrm{mEq} / \mathrm{kg}$ \\
$\begin{array}{l}\text { Bilangan p-anisidin } \\
\text { (mEq/kg) } \pm \text { SD }\end{array}$ & $11,5710 \pm 0,3595$ & $13,6624 \pm, 9574$ & $9,9625 \pm 2,7789$ & $\leq 20 \mathrm{mEq} / \mathrm{kg}$ \\
$\begin{array}{l}\text { Bilangan total oksidasi } \\
\text { (mEq/kg) } \pm \text { SD }\end{array}$ & $26,1225 \pm, 1484$ & $21,6531 \pm 1,8150$ & $25,8976 \pm, 6629$ & $\leq 26 \mathrm{mEq} / \mathrm{kg}$ \\
\hline & & & \\
\hline
\end{tabular}

Hasil karakteristik mutu minyak ikan layang setelah pemurnian berupa kadar bilangan asam lemak bebas pada semua konsentrasi bentonit memenuhi persyaratan IFOS yaitu $\leq 1,50 \%(\mathrm{~b} / \mathrm{b})$. Konsentrasi bentonit dengan nilai bilangan asam lemak bebas terendah terdapat pada konsentrasi bentonit $1 \%$ yaitu $0,2449 \pm 0,0296 \mathrm{mEq} / \mathrm{kg}$. Hasil uji bilangan peroksida pada konsentrasi 1 dan 5\% tidak memenuhi persyaratan IFOS dan pada konsentrasi 3\% memenuhi persyaratan IFOS yaitu $3,9953 \pm 0,0742 \mathrm{mEq} / \mathrm{kg}$.

Hasil uji bilangan $p$-anisidin pada semua konsentrasi bentonit sesuai persyaratan IFOS yaitu $\leq 20 \mathrm{mEq} / \mathrm{kg}$. Konsentrasi bentonit dengan nilai bilangan $\mathrm{p}$-anisidin terendah terdapat pada konsentrasi bentonit 5\% yaitu 9,9625 $\pm 2,7789 \mathrm{mEq} / \mathrm{kg}$. Hasil bilangan total oksidasi minyak ikan layang pada konsentrasi 1 dan 5\% tidak memenuhi persyaratan IFOS, pada konsentrasi 3\% memenuhi persyaratan IFOS yaitu $21,6531 \pm 1,8150 \mathrm{mEq} / \mathrm{k}$.

Hasil statistik SPSS menggunakan uji one-way ANOVA menunjukkan bahwa perbedaan konsentrasi bentonit tidak memberikan pengaruh terhadap bilangan total oksidasi. Hal tersebut ditunjukkan dengan nilai signifikasi sebesar 0,086 yang artinya tidak ada perbedaan nyata terhadap bilangan peroksida dengan penggunaan bentonit konsentrasi 1, 3, dan 5\%.

Kejernihan memiliki peranan sebagai daya tarik bagi konsumen dalam memilih minyak ikan. Kejernihan yang tinggi pada minyak menunjukan bahwa pengotor-pengotor yang terdapat pada minyak tersebut semakin sedikit. Berdasarkan hasil penelitian yang dilakukan, kejernihan minyak ikan layang tertinggi setelah dimurnikan terdapat pada konsentrasi bentonit 3\% (Gambar 
2) dengan persentase transmisi pada panjang gelombang $(\lambda) 450,550,620$, 665, dan $700 \mathrm{~nm}$ berturut-turut yaitu $74,6996 \pm 1,9363 ; \quad 94,4950 \pm 1,5724$; $95,1060 \pm 1,667 ; \quad 95,6906 \pm 1,4371$, dan $95,9356 \pm 1,3427 \quad \%$ T. Hal ini menunjukkan bahwa nilai persentase transmisi cahaya tertinggi mendekati 100\% dan mendekati transmisi cahaya minyak komersial sehingga memiliki tingkat kejernihan yang baik. Korelasi hubungan antara nilai persentase transmisi dengan tingkat kejernihan minyak adalah semakin tinggi nilai persentase transmisi maka semakin kecil kadar zat warna yang terdapat dalam minyak tersebut. Hasil penelitian tersebut juga menunjukkan bahwa nilai persentase transmisi kejernihan minyak ikan layang mengalami peningkatan dari hasil analisis karakteristik minyak ikan layang kasar. Hal ini disebabkan karena bentonit yang telah teraktivasi mampu memperbaiki warna minyak.

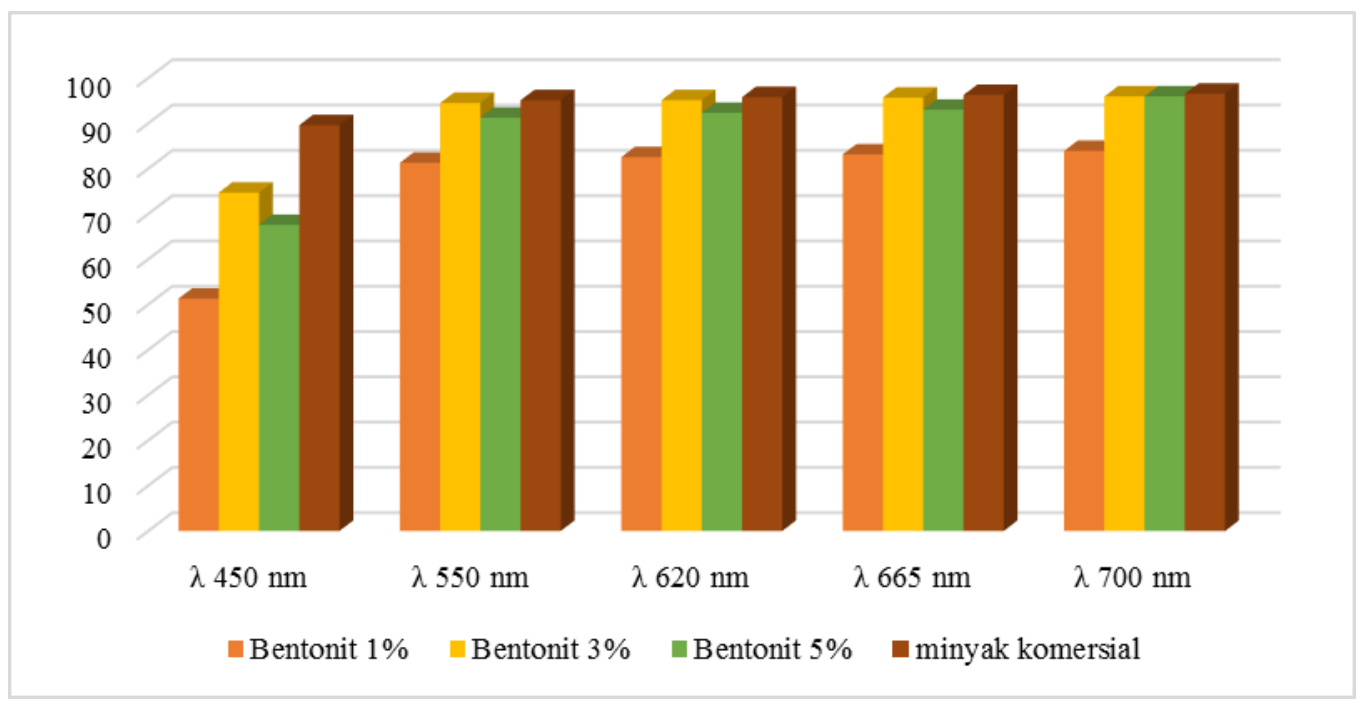

Gambar 2. Grafik kejernihan minyak ikan layang (Decapterus ruselli) murni.

\section{Kesimpulan}

Berdasarkan penelitian yang telah dilakukan, dapat disimpulkan bahwa pemberian bentonit berpotensi sebagai adsorben dalam proses pemurnian minyak ikan kasar. Hasil pemurnian minyak ikan layang terbaik adalah pada pemberian bentonit konsentrasi 3\%, yang menghasilkan minyak ikan yang memenuhi persyaratan 
IFOS dengan nilai kadar asam lemak bebas sebesar $0,4406 \pm 0,0265 \%(b / b)$; bilangan peroksida sebesar $3,9953 \pm 0,0742 \mathrm{mEq} / \mathrm{kg}$; bilangan $\mathrm{p}$ anisidin sebesar $13,6624 \pm 1,9574$ $\mathrm{mEq} / \mathrm{kg}$; bilangan total oksidasi sebesar 21,6531 $\pm 1,8150 \mathrm{mEq} / \mathrm{kg}$; dan kejernihan

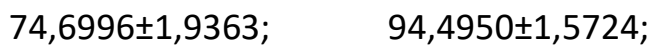
$95,1060 \pm 1,667 ; \quad 95,6906 \pm 1,4371 ; \quad$ dan 95,9356 $\pm 1,3427 \%$ pada panjang gelombang berturut-turut $450,550,620$, 665, dan $700 \mathrm{~nm}$. Hasil uji one-way ANOVA dan uji Kruskal-Wallis menunjukkan perbedaan konsentrasi bentonit terdapat perbedaan nyata terhadap nilai analisis bilangan asam lemak bebas dan kejernihan, namun tidak berbeda nyata terhadap nilai analisis bilangan peroksida, $\mathrm{p}$-anisidin, dan bilangan total oksidasi.

\section{Daftar Pustaka}

Estiasih, T. 2009. Minyak Ikan: Teknologi dan Penerapannya untuk Pangan dan Kesehatan. Yogyakarta: Graha IImu.

Handayani, K. dan Yusnimar. 2013. Pengaruh ukuran partikel bentonit dan suhu adsorpsi terhadap daya jerap bentonit dan aplikasinya pada bleaching CPO. Teknobiologi: Jurnal Ilmiah Sains Terapan, 4(2):117-121.
Hidayaturrahmah, Muhamat, Akbar, A. 2016. Efek ekstrak minyak ikan patin (Pangasius hypopthalmus) terhadap peningkatan memori dan fungsi kognitif mencit berdasarkan passive avoidance test. Jurnal Pharmascience, 03(02): 14-22.

Minarny, G., Purnomo, H., Asriani, Rosyidi, D. 2014. Fatty acid profile of fish from Central Sulawesi, Indonesia. International Food Research Journal, 21(3):979-983.

Sutarjo, G.A. 2017. Analisis kadar protein dan kadar lemak pakan ikan gabus dalam bentuk cake dengan konsentrasi ikan layang (Decapterus sp.) yang berbeda. Prosiding Seminar Nasional III: Biologi, Pembelajaran, dan Lingkungan Hidup Perspektif Interdisipliner. 29 April 2017. Universitas Muhammadiyah Malang.

Suseno, S.H., Musbah, M., Ruspatti, N.P. 2016. Karakteristik minyak ikan murni sardin (Sardinella sp.) dan cucut (Centrophorus Sp.) sebagai bahan suplemen makanan kaya omega-3 dan squalen. Prosiding Seminar Nasional Kelautan. 27 Juli 2016. Universitas Trunojoyo Madura. 